\title{
ПРОБЛЕМИ ПІДВИЩЕННЯ ПРОФЕСІЙНОЇ КОМУНІКАТИВНОЇ КОМПЕТЕНТНОСТІ МАЙБУТНЬОГО ОФІЦЕРА
}

\begin{abstract}
Лозинський П. I. Проблеми підвищення професійної комунікативної компетентності майбутнього офіцера

У статті розглянуто проблему професійної іноземної підготовки курсантів у вищих військових навчальних закладах. Автор визначає, що практичні заняття 3 англійської мови повинні задовольнити потреби курсантів вищих військових навчальних закладів в сучасному світі. Запропоновано шляхи підвищення професійної комунікативної компетентності майбутнього офіцера 3 метою спілкування на міжнародному рівні.

Ключові слова: комунікативна компетентність, військовий навчальний заклад, комунікативні здібності, мотивація, професіоналізм.
\end{abstract}

Лозинский П. И. Проблемы повышения профессиональной коммуникативной компетентности будущего офицера

В статье рассмотрена проблема профессиональной иностранной подготовки курсантов в высших военных учебных заведениях. Автор определяет, что практические занятия по английскому языку должны удовлетворить потребности курсантов высших военных учебных заведений в современном мире. Предложены пути повышения профессиональной коммуникативной компетентности будущего офицера с целью общения на международном уровне.

Ключевые слова: коммуникативная компетентность, военное учебное учреждение коммуникативные способности, мотивация, профессионализм.

Lozinsky P. I. Problems of improvement of the professional communicative competence of an officer.

The paper highlights problems of the foreign language preparation of the cadets of high military institutions. The author states that practical English classes should meet the needs of students of higher military educational institutions in the modern world. The ways of increasing of the professional communicative competence of future officers in order to communicate at the international level are proposed.

Key words: communicative competence, military institution, communicative skills, motivation, professionalism.

В умовах сучасності важко уявити вищу школу без вивчення іноземної мови. Мета навчання іноземним мовам у вищих навчальних закладах на не філологічних спеціальностях спрямована на оволодіння мовленнєвою компетенцією 3 іноземної мови для спілкування в соціально-побутових сферах людської діяльності. При цьому відповідна увага повинна приділятися навчанню мові спеціальності, іншими словами для спеціальних професійних цілей [1, с. 3].

Професійна спрямованість вивчення іноземних мов у військових закладах ставить низку завдань із розвитку професійних навиків у курсантів: оволодіння професійною лексикою, вміння комунікативних навиків професійного спілкування, формулювання власної точки зору на професійну тематику, тощо. Головним і пріоритетним завданням вивчення іноземних мов $€$ розвиток комунікативних 
здібностей, тобто підвищення рівня комунікативної компетентності 3 метою спілкування між фахівцями різних країн та різних галузях знань.

Mema cmammi- розкрити проблему підвищення іншомовної комунікативної компетентності майбутнього офіцера та визначити умови для успішного вивчення іноземної мови у вищому військовому навчальному закладі.

3 розвитком потреб суспільства змінювались акценти вивчення іноземних мов у вищому навчальному закладі, необхідністю стало формування іншомовної комунікативної компетентності. Проблема розвитку комунікативної компетентності в процесі вивчення іноземної мови досліджувалась у працях Л.Биркун, О. Вишневського, І. Зимньої, Ю. Пассова, Т. Сірик та ін. Поняття комунікативної компетентності як узагальненої комунікативної властивості особистості розглядаються в роботах О. Бодальова, Ю. Ємельянова, В. Кан- Калика, О. Киричука, Я. Коломинського, О. Крилова, Н. Кузьміної, І. Ладанова, А. Панфілової, Л. Петровської, В. Сластьоніна, В. Семіченко, Н. Тарасевич, Т. Яценко та ін. Більшість вчених вважають комунікативну компетентність вагомою складовою професійної компетентності, яка має в кожному виді діяльності свою специфіку.

Комунікативна компетентність - здатність особистості застосовувати у конкретному виді спілкування знання мови, способи взаємодії з людьми, що оточують iii та перебувають на відстані, навички роботи у групі, володіння різними соціальними ролями.

Сучасні підходи і трактування професійної компетентності досить різні. Найчастіше це поняття вживається для вираження високого рівня кваліфікації й професіоналізму. Вивчення іноземних мов у військових навчальних закладах Збройних Сил України необхідне в контексті сучасної освіти, найважливішою рисою якої $є$ iï спрямованість на те, щоб готувати військових фахівців не тільки для адаптації, але й для активного пізнання ситуації соціальних змін.

Професійну компетентність майбутнього офіцера можна представити як якісну характеристику особистості фахівця, що охоплює систему науково-теоретичних знань, у тому числі спеціальних знань у галузі військової науки, професійних умінь i навичок, досвіду, наявність стійкої потреби у набутті компетентності, інтересу до професійної компетентності свого профілю. Необхідно застосовувати пропоновані знання у нових умовах, які потребують навичок іншомовного спілкування.

Одним із важливих завдань мовної освіти є: сформувати вміння й навички вільного вираження думок і почуттів в усіх видах мовленнєвої діяльності: аудіюванні, читанні, говорінні, письмі і в різних сферах спілкування: особистісній, публічній, освітній, оволодіти культурою мовлення, тобто виробити комунікативну компетентність особистості [2, с. 15]. Все частіше в навчанні майбутніх офіцерів, формуванні їхньої професійної, комунікативної компетентності застосовується компетентнісний підхід. Компетентнісний підхід - це підхід, що акцентує увагу на результатах освіти, причому в якості результату розглядається не сума засвоєної інформації, а спроможність людини діяти в різних проблемних ситуаціях [3, с. 143].

Для того, щоб майбутній офіцер міг брати участь у діалозі культур із представниками Збройних Сил інших країн, він повинен володіти комунікативною іншомовною компетенцією, яка дозволить йому нарівні висловлювати свою думку, захищати власну точку зору, стверджувати або заперечувати думку інших, погоджуватися або не погоджуватися 3 нею у певній комунікативній ситуації. Звідси випливає проблема професійної іншомовної підготовки майбутніх офіцерів. Саме тому формування професійної іншомовної компетентності є актуальним для курсанта ВВНЗ.

Для готовності курсантів ВВНЗ до спілкування на міжнародному рівні 
формування професійної іншомовної компетентності має відбуватися інтегровано, у поєднанні з військовими та гуманітарними дисциплінами ВВНЗ.

Іншомовна комунікативна компетентність $€$ інтегральною характеристикою професійної діяльності фахівця, яка охоплює такі підструктури як діяльнісну, що включає у своє значення уміння, знання, навички та способи здійснення професійної діяльності, а також комунікативну, тобто уміння, знання, навички та способи здійснення професійного спілкування.

Саме дані цілі підвищення іншомовної комунікативної компетентності дали поштовх для уведення професійно зорієнтованого інтенсивного курсу вивчення іноземної мови у навчальний процес військових навчальних закладах, котрий складається з чотирьох напрямів і відбувається перш за все за соціально-побутовим спрямуванням, що дозволяє курсантам опанувати загальновживану лексику, мову для повсякденного, побутового спілкування; лінгвокраїнознавчим спрямуванням курсанти ознайомлюються $з$ особливостями політичного, культурного та економічного життя країни, мова якої вивчається. Фаховий військовий курс іноземної мови для спеціальних цілей, а саме військовий переклад і курс іноземної мови для ділового спілкування, що є типовим для багатьох галузей професійної діяльності пов'язаних 3 веденням кореспонденції як на офіційному, так і на неофіційному рівнях.

Перш за все необхідно зазначити, що вивчення іноземної мови здійснюється на основі ситуацій, що розглядаються на рівні системи взаємовідносин. Ситуація, у свою чергу, визначається як інтегративна динамічна система соціально-статусних, рольових, діяльнісних і моральних взаємин суб'єктів комунікації. Вона постає універсальною формою функціонування процесу навчання, тобто служить способом організації мовленнєвих засобів, а також мотивації мовленнєвої діяльності [4, с. 316$]$.

Важливим компонентом у системі підготовки курсантів до комунікативної діяльності $\epsilon$ набуття навичок поза аудиторної роботи. Цей процес передбачає створення підгрунтя для застосування набутих знань та навичок, варіантів розв'язків, прийомів спілкування в умовах нової комунікативної ситуації; знаходження розв'язків для нової комунікативної ситуації крізь призму комбінування попередньо засвоєними ідеями, знаннями та прийомами та створення нових методів для пошуку розв’язків конкретної комунікативної ситуації.

Розвиток мовленнєвої компетентності тісно пов'язаний 3 формування соціокультурної компетентності, як інтегральної особистої якості, необхідної сьогодні будь-якому фахівцю, але в контексті мовної підготовки особового складу Збройних Сил України ця проблема набуває особливого значення, тому що вона дозволяє людині на основі наявної системи знань визначати свої ціннісні переваги, виходячи 3 яких конструювати свою поведінку і відносини з партнерами по взаємодії, надавати конструктивну відповідь на проблемні ситуації в системах відносин «людина людина», самореалізуватися в конкретних культурно-історичних умовах власної життєдіяльності» $[5$, с. 26].

Соціокультурна компетентність визначається рядом складників. Котрі доповнюють одна одну це $\epsilon$ політична і соціальна компетентність, яка передбачає здатність брати на себе відповідальність, брати участь у совісному узгодженні рішень, брати участь у функціонуванні та розвитку демократичних інститутів, а також культурна компетентність, яка сприяє розумінню відмінностей, готовності жити у згоді з людьми інших культур, мов і релігій.

На їх основі дістає розвитку комунікативна компетентність, яка визначає комунікативні здібності людини, вміння спілкуватися з різними людьми, в середовищі перебування, що передбачає не тільки вміння розмовляти, не тільки правильно 
формулювати свої думки як в усній, так і в письмовій формі, але й уміння шукати й знаходити компроміси, поважати іншу думку.

Важливим напрямом у вивченні іноземних мов $\epsilon$ особистісне орієнтоване навчання - це процес, спрямований на досягнення активності особистості та збереження цього стану. Найбільш істотним в плані активізації всього навчального процесу $\epsilon$ максимальне використання можливостей, закладених у практичних заняттях, оскільки при скоєному рівні розвитку комунікативних засобів великого значення набувають такі джерела інформації, як інтернет, листування іноземною мовою, журнали, газети. Активізація занять 3 іноземної мови пов'язана перш за все 3 раціональною організацією пізнавальної діяльності курсантів 3 урахуванням їх індивідуальних здібностей i 3 розвитком уміння швидко орієнтуватися в тексті іноземною мовою, отримувати 3 нього необхідну інформацію. Саме продумана система навчального процесу дозволяє включати предмет іноземну мову в систему міжпредметних зв'язків і тим самим актуалізувати його значення для підготовки курсантів до успішної професійної діяльності в майбутньому.

Слід пам'ятати про швидкий розвиток та особливості іноземної військової мови в умовах технічного прогресу та глобалізації суспільства зокрема англомовне військове мовлення характеризується широким використанням військової термінології, емоційно забарвлених елементів військової лексики, експресивних виразів, чітких нормативних граматичних форм, скорочень в англійській військовій лексиці, специфічних мовленнєвих зворотів та інших мовних явищ, які важко сприймаються без опори на текст.

Лінгвістичні особливості військової лексики пов'язані 3 переосмисленням наявних у мові лексем. До військової лексики передовсім належать усі слова та словосполучення, що означають військові поняття, тобто поняття, безпосередньо пов'язані зі збройними силами, військовою справою, війною тощо. Крім того, до військової лексики варто віднести науково-технічні терміни, що вживаються спільно 3 військовими поняттями.

Особливості англомовного аутентичного мовлення військовослужбовців-носіїв англійської мови пояснюються широким використанням військової лексики, у якій важливе місце відведено військовій термінології та емоційно забарвленим елементам військової лексики і сленгу. Складність сприймання на слух військової термінології зумовлюється одночасним використанням як термінології офіційної, яка складається зі статутних термінів, так і нестатутної термінології, що вживається в усній мові військовослужбовців [6, с. 239].

Сучасна військова лексика перебуває в постійному динамічному русі. Особливо це стосується американської військової та військово-технічної термінології, вона безперервно змінюється за рахунок обмеження функціонування низки слів, зміни значень, безперервного поповнення новими термінами, наприклад, у зв'язку 3 реорганізацією видів збройних сил, виникненням i розробленням нових видів озброєння й бойової техніки, розробкою нових методів ведення війни [7, с. 152]. Такі суттєві фахові особливості військової іноземної мови безпрецедентно впливають на підвищення комунікативної компетентності майбутніх офіцерів.

Умовами успішного навчання іноземної мови є контроль за виконанням усіх дій, що $\epsilon$ складовими відповідної діяльності, увага до всіх внутрішніх і зовнішніх механізмів іï реалізації, удосконалення операційного аспекту, глибокий аналіз спонукально-мотиваційних факторів, кожного виду діяльності, яка характеризується складною взаємодією мотивів, цілей, потреб, інтересів, інтенцій курсантів ВВНЗ і стимулів, що їх спонукають. 
До підвищення мотиваційних ресурсів навчальної діяльності належить відмова від уніфікованих моделей навчання, які ігнорують особистісні характеристики майбутнього офіцера, акцентується увага на гнучкість побудови навчального процесу, варіативність його компонентів, зумовлених природою мотиваційно-спонукальної сфери суб'єкта навчання 3 урахуванням відповідності змістової сторони процесу мотиваційним орієнтаціям курсантів ВВН3 при мотиваційному забезпеченню навчального процесу 3 метою створення режиму діяльності, адекватного мотиваційному підтексту навчання [8, с. 382].

Модель професійної готовності курсантів ВВНЗ до міжнародного спілкування має передбачати мотив, наявний у моделі Ю. Пассова. Система підвищення комунікативної компетентності спрямована на передачу професійної культури. Остання включає чотири компонента: знання; досвід- 3 багатьох причин не доноситься до необхідного рівня;творчість - $\epsilon$ недостатнім при навчанні курсантів та формуванні їх як професіоналів-офіцерів ВВН3; майже повністю ігнорується четвертий компонент - бажання, мотив. Проблема полягає в тому, що без двох останніх компонентів «не працюють» два перших. Знання та досвід залишаються мертвими, якщо відсутні здатність творити та бажання працювати [9, с. 18].

Тому головним завданням системи формування професійної комунікативної компетентності курсантів ВВНЗ є трансляція професійної культури необхідного обсягу та змісту, де чотири компоненти у кожній із військових дисциплін були б представлені в необхідній пропорції та інтегративно допомогли б готувати курсантів ВВНЗ до спілкування на міжнародному рівні.

Військова освіта $€$ визначеним процесом становлення і розвитку особистості та передачі іiі соціального досвіду. Однак, на відміну від цивільної, військова освіта формує особистість військового фахівця, який повинен і здатен займатися військовою діяльністю. Культура мовлення як складник загальної культури $\epsilon$ одним із найважливіших показників цивілізованості суспільства. Процес опанування мови та іiі культури пов'язаний із набуттям навичок правильно розмовляти і писати, точно висловлювати свою думку, активно й грамотно використовувати мовні знання. Час диктує свої вимоги, і нині ситуація з вивченням іноземної мови у вищих військових навчальних закладах значно змінилася. Завдяки духу часу та змінам у свідомості людей яскраво виявилася необхідність у володінні іноземними мовами.

Без сумнівів, професійна підготовка повинна бути:

- професійно спрямованою, тобто стрижнем професійної готовності у ВВНЗ має бути військово-культурна майстерність, підкріплена дисциплінами, які мають обов'язкову професійну спрямованість;

- спрямованою на формування готовності майбутнього офіцера-дослідника, для якого культ пізнання $є$ мотиваційною основою діяльності і породжує пізнавальну активність;

- функціональною такою яка б моделювала зміст та структуру військової діяльності;

- фундаментальною щоб майбутній офіцер мав можливості оволодіти найсучаснішими основами з основної спеціальності;

- давати основи знань з гуманітарних дисциплін;

- інтегровано-спрямованою на трансляцію професійної культури та оволодіння професійною майстерністю, яка допоможе при спілкуванні на міжнародному рівні представникам різних національностей;

- спрямована на забезпечення кожному курсанту ВВНЗ можливостей 
індивідуальної самореалізації;

- соціально-значимою щоб переконати офіцера в соціальній значимості предмета, який він вивчає [10, с. 6].

Важливо сформувати не лише спеціаліста, а й професіонала. Професіоналізмом, 3 точки зору Н. Бакланової, $є$ інтегративна здатність особистості, що відображає взаємозв'язок та змістовне наповнення компонентів, які входять до складу певної здатності - професіональної компетентності, моральності, ініціативи та майстерності. Майстерність не можлива без професіоналізму, без оволодіння певною сумою необхідних професійних знань, умінь та навичок, однак вона ніколи не зводиться до професіоналізму.

Науковцями узагальнено методичні принципи підвищення комунікативної компетентності на основі комунікативно-орієнтованого і професійно спрямованого навчання міжкультурному спілкуванню, які можуть бути застосовані при формуванні готовності курсантів ВВНЗ до міжнародного спілкування. До цих принципів належать:

- принцип навчання IM у контексті діалогу культур;

- принцип бікультурного комунікативного розвитку тих, хто навчається в умовах іншомовного спілкування;

- принцип розвитку комунікативно-мовної культури в поєднанні 3 іншими видами та різновидами культур;

- принцип комунікативно-орієнтованого формування мовних навичок;

- принцип дидактико-психологічної, навчально-комунікативної та міждисциплінарної інтенсифікації навчального спілкування;

- принцип професійно-профільного напрямку іншомовного навчального спілкування;

- принцип автентичності навчальних матеріалів, навчально-комунікативного фону мовної діяльності курсантів, комунікативно-мовного і соціокультурного змісту навчального спілкування.

Дотримання названих принципів, врахування особливостей професійного спілкування сприятимуть формуванню готовності курсантів ВВНЗ до професійної міжнародної взаємодії, підвищать їх здатність виконувати роль суб'єкта діалогу культур, виявляти готовність і здібність до співробітництва 3 іншими народами у вирішенні глобальних проблем людської цивілізації, у відродженні ідеалів гуманізму, в гармонізації відношень людини, природи й суспільства.

Необхідно створити не тільки умови, які 6 формували готовність до міжкультурної комунікації, але й такі, які б сприяли гуманістичному вихованню. 3 точки зору Т. Левченка до них відносяться:

- відмова від уніфікованих моделей навчання, ігноруючих особистісні характеристики того, хто навчається;

- гнучкість побудови навчального процесу, варіативність його компонентів, зумовлених природою мотиваційно-спонукальної сфери курсанта ВВНЗ;

- відповідність змістової сторони процесу мотиваційним орієнтаціям суб'єктів навчання;

- мотиваційну забезпеченість навчального процесу;

- пристосування конкретних навчальних дій до певного суб'єкта навчання;

- створення режиму діяльності, адекватного мотиваційному підтексту навчання.

На заняттях 3 іноземної мови є умови для удосконалення міжособистісного спілкування курсантів. Навички спілкування формуються на заняттях іноземної мови 
за умови засвоєння мовленнєвих функцій повідомлення, питання, коментування, додавання, висловлювання ставлення. Це сприяє розвитку емотивних механізмів спілкування, розвиває соціальну перцепцію. Спеціально підібрані вправи мають на меті тренування різних технік спілкування, адекватного використання таких аспектів, як інтонація, швидкість мовлення, тембр голосу, міміка тощо. У процесі виконання цих вправ виховується повага до іншого співрозмовника, поглиблюються знання про правила етикету. Це означає обов'язкове визнання партнерів як самостійних суб'єктів, при взаємній повазі, збереженні інтересів і результатів кожного в колективній співпраці.

Принцип колективної взаємодії визначає такий спосіб організації навчального процесу, при якому: а) курсанти активно спілкуються один 3 одним, обмінюючись навчальною інформацією, розширюючи за рахунок цього свої знання; б) між учасниками складаються сприятливі взаємини; в) умовою успіху $є$ успіх інших. Умови для колективної взаємодії можливо створити через систему ускладнення видів роботи з текстом, як в умовах аудиторних занять, так і в години самопідготовки; однією з найбільш плідних форм взаємодії може стати робота курсантів у мікрогрупах в години самопідготовки. Спільна робота в умовах особливого психологічного клімату обмежує конкуренцію і перетворює її на співпрацю, де кожен поступає таким чином, щоб, висловлюючи свою індивідуальність, відповідати очікуванням групи і прагнути досягнення визначених цілей. В умовах колективної спільної діяльності формується загальний фонд накопичення інформації, в який кожним курсантом приноситься своя частина і яким користуються всі разом. Цими видами можуть бути: виконання перекладів для потреб спеціальних кафедр, виступи на засіданнях спеціалізованих кафедр та військового наукового товариства, на щорічних науковопрактичних конференціях 3 доповідями, в яких би використовувалися дані зарубіжної преси.

Невід’ємним складниом успішного навчального процесу є передусім побудова стосунків на принципах глибокої взаємоповаги, рівноправного партнерства викладача та курсанта, курсантів ВВНЗ між собою і створення сприятливого моральнопсихологічної атмосфери в колективі.

Отже, сутність процесу формування комунікативних умінь курсантів можна аргументовано розглядати як їхню підготовку до спілкування в різних умовах професійної діяльності. В iї основі - рівноправна взаємодія суб'єктів цього процесу. Такий підхід передбачає комплексне використання сукупності засобів навчання іноземної мови, а також побудову цілісного навчально-виховного процесу у ВВНЗ 3 метою формування у курсантів комунікативних умінь, а звідси й їхньої комунікативної компетентності.

Результатом необхідності підготовки конкурентоспроможних спеціалістів в різних галузях діяльності на світовому рівні стала потреба змінити відношення до вивчення іноземної мови у вищих військових вузах.

Важливим фактором розвитку системи військової освіти $є$ міжнародні зв'язки ВВНЗ з військовими навчальними закладами іноземних держав. Встановлені тісні зв'язки $з$ провідними військовими навчальними закладами США, Німеччини, Італії, Великої Британії, Греції, Туреччини тощо. Головним практичним завданням ВВНЗ $€$ створення професійно підготовлених, якісно озброєних, всебічно забезпечених, мобільних, багатофункціональних Збройних Сил із характерними ознаками європейської моделі. 


\section{Література}

1. Дудікова Л. Сучасні підходи викладання іноземних мов на не філологічних спеціальностях вищих навчальних закладів/ Л. Дудікова [Електронний ресурс].Режим доступу до джерела: http://www.social-science.com.ua/article/1021

2. Пассов Е. И. Культурообразная модель профессиональной подготовки учителя: философия, содержание, реализация // Иностранные языки. - 2002. - № 4. - С. 11-18. 3. Гончарова О. М. Теоретико-методичні основи особистісно орієнтованої системи формування інформативних компетентностей студентів економічних спеціальностей : дис. доктора пед. наук : 13.00.02 / Оксана Миколаївна Гончарова. - Київ, 2007. - 490 с. 4. Finegan E. Language : its structure and use/ Edward Finegan, Niko Besnier. - San Diego - London: Harcourt Brace Jovanovich, 1989. - 546 p. 5. Закір'янова I. А. Формування соціокультурної компетентності у майбутніх вчителів іноземної мови і процесі професійної підготовки: дис... канд.пед.наук / Ірина Аксанівна Закір'янова. Київ, 2006. - 174 с. 6. Балабін В. В. Сучасний американський військовий сленг як проблема перекладу /В. В. Балабін. - К. : Логос, 2002. - 315 с. 7. Василенко Д. В. Військова лексика англійської мови XX - початку XXI століття/Д. В. Василенко. Горлівка : Вид-во ГДПІІМ, 2009. - 220 с. 8. Левченко Т. І. Розвиток освіти та особистості в різних педагогічних системах / Т. І. Левченко. - Вінниця: «Нова Книга», 2002. - 512 c. 9. Пассов Е. И. Культурообразная модель профессиональной подготовки учителя: философия, содержание, реализация/ Е.И. Пассов. // Иностранные языки. - 2002. - № 4. - С. 18-21. 10. Пассов Е. И. Коммуникативное иноязычное образование / Е. И. Пассов. - Липецк, 1998. - 157 с.

\section{РОЗВИТОК ПРОФЕСІЙНОГО МОВЛЕННЯ СТУДЕНТІВ ЯК ЗАСІБ ФОРМУВАННЯ МОВНОЇ ОСОБИСТОСТІ МАЙБУТНЬОГО ВЧИТЕЛЯ}

Махінов В. М. Розвиток професійного мовлення студентів як засіб формування мовної особистості майбутнього вчителя.

Актуальність дослідження обумовлена значущістю підготовки мовної особистості майбутнього вчителя засобами професійного спілкування під час навчання іноземної мови як системи знань, умінь та навичок, що сприяють розвитку соціокультурної компетенції студентів, формуванню світогляду, моралі та поведінки, готують до професійної діяльності.

Ключові слова: мовна особистість, професійне спілкування, соціокультурний компонент змісту навчання, комунікативна компетенція, міжкультурна комунікація, загальноєвропейський освітній простір.

Махинов В. Н. Развитие профессиональной речи студентов как средство формирования языковой личности будущего учителя.

Актуальность исследования обусловлена значимостью подготовки языковой личности будущего учителя средствами профессионального общения при изучении иностранного языка как системы знаний, умений и навыков, которые содействуют развитию социокультурной компетенции студентов, формированию мировоззрения, морали и поведения, готовят к профессиональной деятельности.

Ключевые слова: языковая личность, профессиональное общение, социокультурный компонент содержания обучения, коммуникативная компетенция, межкультурная коммуникация, общеевропейское образовательное пространство. 